\title{
Property Rights and Environmental Conflicts in Africa: An Exploration of the Main Issues
}

\author{
*Matsa Mark and *Mutekwa Timothy.
}

\begin{abstract}
Shared resources often engender environmental conflict. This is because the activities of some groups of users of a resource are often detrimental to others. This paper discusses the relationship between property rights and environmental conflicts in Africa. It illustrates this relationship both at intra-state as well as at inter-state levels. Gender relations and property rights are also discussed given that women, who undertake about $80 \%$ of farm work on the continent, are not accorded equal say as men in resource ownership and resource management. The paper suggests how the problem of resource ownership can be addressed in order to minimize or prevent environmental conflicts and promote development at country as well as at continental level.
\end{abstract}

\section{Introduction}

Since time immemorial, rural use of common property resources (CPRs), which include inter alia lakes, rivers, wetlands, rangelands and forests. In most colonial and post-colonial Africa, the introduction and application of the government or private property management systems have ignored or sidelined the locally adapted, time-tested, subtle and complex common property resource use practices and management systems obtaining among most of the African rural communities. These modern resource management systems have eroded and in some cases completely rendered the traditional modes of resource exploitation obsolete. This was despite the fact that modern property rights regimes such as state governance and private property regimes are not viable options because many of the resources under the CPRs class are nonexclusive in nature (Magrath, 1989 cited in Berkes, 1993).

The imposition of the modern management systems in the utilization of CPRs has therefore led to the inevitable degradation of the resources because these systems lack a consensually agreed set of conventions, norms and guidelines. This has resulted in environmental conflicts as developing communities ignore the modern management systems, which they view as alien and therefore interference in their way of life. Among the most common causes of CPR related conflicts are land entitlements, water rights and access to fuel wood supplies. The degradation and depletion of these resources further intensifies conflict as the resource base shrinks to accommodate more users given the ever-growing population. It is therefore important to plan and introduce management systems that ensure sustainable exploitation of CPRs to reduce the rate of their continued decline. This paper discusses both intra-state and inter-state property rights and environmental conflicts in Africa. The gender aspect to the ensuing discussion is also considered before recommendations towards possible better management of CPRs are proposed.

\section{The concepts of CPRs, property rights and environmental conflict}

The term common property resources (CPRs) are often used synonymously with common pool resources (Tevera and Mukora, 2001). These terms connote resource types or facilities that are owned by an identifiable community or a group of people and are de facto, if not de jure, accessible to and jointly utilized by all members of the community. Such resources include but are not restricted to fish, wildlife, forests, grazing lands, ground water and rivers.

Common Property rights refer to the laws and rules governing the management of natural resources that are not owned by a single entity, person or family and access to which is limited to an identifiable community of users who can exclude others and regulate use (Tevera and Mukora, 2001). These rights have also been defined by Hackett (1998) as the laws and rules that govern access, withdrawal (use of resource units), management (how and when the resource is accessed or maintenance is performed or use is monitored), and exclusion (determining who can and cannot access or use the resource). The holders of these rights are sometimes known as "proprietors," and management and alienation (sale of the resource) rights are usually exercised in a collective-choice context along with other proprietors. The main challenge associated with the management of CPRs is the difficulty in effectively enforcing the laws and rules that govern the resources so as to exclude or control access of potential users and also the fact that each user is capable of subtracting

\footnotetext{
* Department of Geography \& Environmental Science Midlands State University, Gweru Zimbabwe mutekwat@msu.ac.zw
} 
from the welfare of all other users (Berkes, 1993). The resource classes that fall into the category of CPRs therefore run a risk of being depleted and degraded despite the existence of the governing rules and laws.

The concept of conflict encompasses a broad spectrum of empirical phenomena ranging from disputes between individuals to wars between states. An environmental conflict is a conflict caused by the environmental scarcity of a resource, which is, caused by a human-made disturbance of its normal regeneration rate (Libiszenski, 1992). Environmental scarcity can result from the over stressed ecosystem's carrying capacity. The quarrels between radical environmentalists and industry can as well be called "environmental conflicts" such as wars over fresh water stocks (Libiszenski, 1992). Environmental conflicts thus manifest themselves as political, social, economic, ethnic, religious, ideological, and territorial or conflicts over resources or national interests among others.

The activities of some groups of users of a resource can be detrimental to others. For example, one of the most pervasive kinds of fisheries conflicts in the world concerns that of small-scale inshore fisheries against largescale operations such as trawlers (Berkes, 1989). The appearance of powerful outside interests often combines with the disappearance of community-based management systems. The commons dilemma develops when there are too many users to a limited resource. Allocative disorder arises when the limits to access and /or the right-touse are under specified or not enforced and there are demands on the ecosystem that conflict with sustainability or other users, leading to the possibility of conflict and degeneration of the resource (Berkes, 1989).

The actual strength of a right depends on whether it is considered legitimate locally, whether it is enforceable and whether it can be protected from other people's claims. Where titles and other statutory rights are rejected locally, they may be very difficult to enforce (Hilhorst, 2002). Moreover, usufruct rights that are embedded in customary systems can provide sufficient guarantees for production and do not hinder investment. Cotton in the Sahel, for example, which is an important export crop, is overwhelmingly grown on fields managed by customary tenure systems (Hilhorst, 2002).

\section{Intra-state property rights and environmental conflicts}

The experiences of the Basarwa people in the hands of the Botswana government give a good appreciation of the relationship between property rights and environmental conflicts in Africa. This can be demonstrated using the following two examples: Firstly, in Botswana, land policy allows for three forms of land tenure, that is, state land (which prior to independence in 1966 was referred to as Crown land), tribal land and freehold land. Non-tribal land included land inhabited by tribes or communities not "officially recognized" by the colonial government such as the Basarwa people who are living in the remote Kalahari Desert. When the Kalahari Desert was declared Crown land, the Basarwa and other inhabitants became unlawful occupiers on their traditional lands.

The major implication of the declaration was the denial of the land entitlements to specific groups and this contributed to the marginalization still being experienced by the Basarwa (Mogwe and Tevera, 2000). Central Kalahari Game Reserve (CKGR) was established in areas formally occupied by the Basarwa with no entrenchment of any rights for the Basarwa and available evidence suggest that the Basarwa were coerced by government to move and had done so due to fear of possible reprisals if they remained in the CKGR (Mogwe and Tevera, 2000). However, some communities have, nevertheless, refused to move, arguing that the land belongs to them as the indigenous people of the area whose arrival predated that of the Bantu-speaking peoples in the country.

Secondly, under customary law in Botswana, individuals are entitled to be allocated land according to need, which is generally interpreted to mean their ability to use the land. However, the rural poor like the Basarwa inevitably lack the capacity to utilize the land productively due to their marginal location and an acute shortage of resources such as draught power.

Government interpretation of land use patterns as confined to the sedentary communities displays little appreciation for the hunter-gatherer land uses, effectively discriminating against the Basarwa. Due to the lack of recognition of the rights of the Basarwa, much of their traditional land territories were allocated to other groups for use as ranches or cattle posts (Mogwe and 
Tevera, 2002). The result has been resentment of government and land disputes with occupier sedentary communities coupled by the intensification of land and resource use conflicts and the subsequent reduction in wildlife numbers, diminishing of veld products and intensification of poverty among the Basarwa community.

At the centre of environmental conflicts in Namibia, lies a land tenure system that was based on an equitable distribution of land along racial lines (Moyo, et al, 1993). This land tenure system mirrors land tenure systems which prevailed in other African countries such as pre-independence Zimbabwe, Kenya and Zambia.

Prior to independence in Namibia, white settlers, who constituted just $8 \%$ of the population owned and held freehold title to $60 \%$ of the agricultural land (Moyo et al, 1993. The land tenure system gave whites freedom to purchase or sell land and to borrow money from leading institutions using their farms as collateral. In sharp contrast, $40 \%$ of national land held by blacks in the ' homelands' could not be sold or purchased freely because it belonged to the community.

Apart from being small, homelands and reserves are marginal areas characterized by poor climate, soils and inadequate resources. Environmental conflicts arose in Ovamboland when some unscrupulous commercial game ranchers who often graze their animals in the open rangelands in the rainy season illegally fenced part of the communal land thereby reserving their own grazing land for the dry season. This resulted in protests and in some cases increased cases of poaching by the communal people (Moyo et al, 1993).

In Tanzania, there are 4 types of land tenure systems. These are government leaseholds; rights of occupancies; customary land tenure laws and the collective tenure systems. However, land tenure systems in pastoral areas can be treated as a special case (Berkes, 1989).

Most of the pastoralists use communal grazing areas and cattle are shifted to other areas with more pasture if drought occurs in the more arid regions. Usually these pastoralists return when vegetation recovers. This migration type of grazing enables pastoralists to use their land more sustainably. However, arable land has expanded in response to demand due to population growth, thus causing the shrinkage of pastureland.
Consequently, overstocking has become a problem in places like Dodoma, Arusha and Mwanza, forcing pastoralists to migrate permanently to other regions like Iringa, Rukwa and the coastal regions where pasture is available for most of the year (Moyo et al, 1993). The local people in these regions, mainly the sedentary peasants have conflicting relationships with migrant pastoralists, especially disputes and fights when cattle accidentally stray and graze on growing crops.

In Zambia, there are 3 categories of land, namely state, reserve and trust lands (Moyo et al). Reserves, which are for the sole use of indigenous people are administered under customary or traditional land tenure systems. State land, on the other hand, is used exclusively for commercial farming, townships and the transport and communication infrastructure, and is administered under the statutory leasehold system. The trust land is reserved for the benefit of the population in future when the need arises, for example, for resettlement. The essence of customary systems is based on clearly defined user rights with the traditional authorities exercising overall jurisdiction and responsibility. The principle of a communality of interest in the land, most evident in the use of land for grazing, drawing water, firewood collection, hunting and fruit gathering is balanced by the recognition of the value of individual crop production. Land is considered to be owned by the community for the benefit of the community.

Traditional norms imply that a share in the village lands is viewed as a birthright by the descendants of the land-holding family regardless of where they leave (Moyo et al, 1993). It is against this birthright notion attached to land that land disputes have arisen in cases where peasant farmers long to return to their ancestral land that was appropriated by colonial authorities. This has led to some instances where peasant farmers have resorted to squatting on state designated commercial farms or on abandoned commercial farms (Sakala Commission, in Moyo et al 1992).

In Ethiopia, the establishment of the Awash Valley Authority in 1962 and the investiture of land ownership were primarily to supervise development in the Awash Valley and settle the Afar pastoralists on two irrigated settlement schemes (Tevera and Moyo, 2000). This however deprived the Afar pastoralists of their right of seasonal movement. The Afar pastoralists graze their cattle close to the 
riverbanks during the dry season and move the cattle onto the escarpments during the rainy season to escape floods and mosquitoes. They have a contractual system with the Highlanders who are cultivators. By selling some of their cattle and acting as herders for the cultivators, the Afar's are able to pay an agreed amount to let their cattle graze on the cultivator's crop residues. This arrangement of the rules governing the use of the commons satisfied both groups.

However, when the Afar pastoralists were settled to give way for commercial irrigation settlements, their seasonal migration from the lower plains to the highlands in the Awash Valley was discontinued. Yet this wellestablished system of land use, migration and reciprocity with the highland cultivators was the way the Afar overcame the ecological constraints (Moyo et al, 1993). With the breakdown of the patterns of reciprocity came conflict between the Afar and the Highlanders over the access to land.

This example serves to illustrate how uninformed state interventions may destroy highly sophisticated and adapted methods of conserving natural resources following a tradition of long empirical experience and orally transmitted knowledge in local communities.

In Zimbabwe, most of the black population which fought the liberation war on the basis of reclaiming land rights tended to mobilize people's energies and will as they thought that they were fighting for a just cause (Matondi, 2000). When the promises for land expropriation made by the liberation movements did not yield the desired results, the rural people were disappointed and this resulted in illegal farm occupations in the 1998/99 agricultural season.

Another case of property rights versus environmental conflicts in Zimbabwe is in Bulilima and Mangwe districts where local households and outsiders collect mopane worms (amacimbi) without reference to anyone when they are in season (Madzudzo, 1998). A constraint among local collectors is the fact that this is the time when they are busy working in the fields. Conflict arises when people from outside the district come; by public or private transport to collect mopane worms while the locals are busy in the fields. These outsiders collect mopane worms throughout the week which the locals cannot do because of their busy work schedule. The local community has thus been urging the
Rural District Council (RDC) to exclude outsiders from harvesting amacimbi (Madzudzo, 1998). Local communities are constrained to deal with outsiders. They look up to the RDC to legitimize their claims to exclude outsiders.

Inter-state property rights and
environmental conflicts. Transboundary natural resources are those whose access and benefits are claimed by several nation states (Tevera and Mukora, 2001). Shared water systems, migratory wildlife and establishing the extent of the watershed beyond national boundaries are some of the key problem areas (SADC/IUCN/SARDC, 2001). Examples of transboundary common resources in Southern Africa in the form of shared watercourses are the Zambezi River Basin, Limpopo River System and Orange River.

In recent years, a number of serious conflicts have been observed in the Zambezi Basin. For example, the Zimbabwean and Zambian governments have been involved in a protracted conflict on the building of the Batoka Gorge Dam on the Zambezi River (Chiuta, 2000). Although this is one of the planned projects that have been on the cards for a long time, Zambia feels that the Batoka Gorge is not a priority for Zambians since they have not yet exhausted the current installed hydropower. Zimbabwe, on the other hand is desperate to boost its hydroelectric power through the construction of the dam and subsequent establishment of an HEP station.

In the Eastern Caprivi region of Namibia, conflict is escalating between tourism facility operators and fishing communities as more and more land on the river frontage is leased for tourism, and many fishing communities in both Namibia and Zambia are denied access to fishing grounds (Chiuta, 2000). A number of fishing communities in these areas have complained that their fishing nets are being destroyed by the tour operators, while the tour operators are arguing that these fishing communities are over fishing the waters, thereby affecting their angling business.

In the Chobe/Caprivi area, a crossborder veld burning exists between Namibia and Botswana (Tevera and Moyo, 2000). In Botswana, the Chobe River frontage is used for tourism and wildlife, while in Namibia the frontage is used for communal agriculture and cattle grazing. Bird watching on a small 
wooden canoe (mokoros) is also an important activity.

Conflict between wildlife management and cattle grazing has resulted in Namibian cattle being shot on the Botswana side and stray wildlife from Chobe National Park killed in Namibia. In the same area, there is also a land dispute between the two countries over a small island called Sidudu (Chiuta, 2000). The tensions in this area are so intense that there is a permanent military presence.

In West Africa a bitter dispute has been raging between Nigeria and Cameroon over the Bakassi Peninsula, which both countries claimed as belonging to them. This was mainly because the island is oil-rich. The dispute was only settled after the intervention of the International Tribunal in The Hague. The peninsular was only given back to Cameroon in 2005.

\section{Property rights, environmental conflicts and} gender

Gender issues are paramount in any discussion of property rights and environmental conflicts issues. Though women form the backbone of peasant agriculture, their lowly position in society hinders the realization of their full contribution to development efforts (Westing, 1986). Women, who undertake about $80 \%$ of farm work, are not accorded an equal say in their operations. Not only do men remain in charge of farm planning and management, but the land tenure systems condemns women to membership of a "landless class" (Ribbot, 2001). Even where land is acquired, women in several African societies are considered as legal minors and therefore not entitled to hold title deeds. In Zimbabwe, for example, although women are free to apply for land in the resettlement areas under Model A1 or Model A2 schemes, under Model A1 women face discrimination as they are required to submit their application through the traditional leadership which itself is male-dominated. The patriarchal tendencies have hindered women from accessing and owning land (Mgugu and Chimonyo, 2004). The A2 model requires a certain minimum amount of resources to be owned by the applicant indicating that they have the potential for commercial farming. This is despite the fact that most women own such resources through their husbands and that most rural household are headed by females.

Women often use CPRs intensively, collecting fuel wood and a wide range of other products from common lands, including grasses, medicines, fruits, nuts and berries. Harvesting strategies, such as where, when, how and with what intensity to gather and collect environmental resources determines the sustainability of the resources utilization. Regulation of resources use is more likely when the individual can reasonably expect to benefit in future from such restrictions (Boland and Platteau, 1996). For example, in West Africa women may be reluctant to invest in long term soil fertility improvement if they are not sure that they will be able to cultivate the same field the following year (Hilhorst, 2002).

Equally, they may be less eager to change fuel wood cutting techniques, leave unripe fruits to mature or protect a certain area if they fear that others will not respect such restrictions, reaping most of the benefits. For most rural people, access rights are obtained through customary rights systems (Lavigne, 2002). Women's claims to land within customary systems are generally obtained through their male members and hence may be considered secondary or derived rights. When access to a plot is granted to a woman in Niger, it may be on land which other male relatives do not want, because, for example, it is not very fertile, difficult to work, or not suitable for animal traction (Toulmin, 1997).

In some societies or families, women's access to land may be constrained by their men fork's fear for perceived independence that this access may generate. Some men in Cameroon, for example, refuse to give land to their wives since they fear they will lose a wife's labour on their own fields or they may not like the idea women earning their own money (van den Berg, 1999)

Islamic law however recognizes a woman's right to inheritance, although her share is usually smaller than that of a male relative. This has resulted in some women changing religion to improve their daughter's rights to land, as has been the case in Cameroon (Cooper, 1997).

\section{Conclusion}

From the preceding discussion, it would appear that restricting resource use through regulations could best enhance sustainability of CPRs. However, this require clarity about decision- making capacity over CPRs, as well as the presence of effective and respected institutions which oversee a fair application of rules, monitor results and propose changes. Customary authorities remain important for managing resource use effectively. Their authority in matters of tenure 
as well as conflict resolution is recognized by resource users even when official legality is lacking. Land policy for CPRs should therefore take more account of local ways of dealing with land and emphasis should be on security of rights and prevention of conflict with institutions and authority systems becoming key. This would result in the reduction of both intra-state and inter-state environmental conflicts and a possibility of the achievement of the goal of sustainable development at all levels and in all regions across the African continent and the world. In the light of the complexity of property right and environmental conflicts as discussed in this paper the following recommendation can be useful hints for stakeholders on environmental conflicts management in Africa:

- The strengthening of existing community institutions of natural resource management through capacity building is essential, provided the resource users and appropriate stakeholders pay careful attention to the design of institutions. These should conform to the local forms of control and conflict resolution mechanisms (CAMPFIRE is a good example in Zimbabwe). The presence of government or outside institutional representatives evokes mistrust.

- To address conflicts from shared water courses like the Zambezi River, appropriation rules must restrict when, how, where and how much an appropriator can withdraw from the river. These rules must include consideration of variations due to

\section{References}

Berg, A. van den (1997) Women Farmers in Pursuit of Land Security: And What About Sustainability? Thela Publishers, Amsterdam.

Berkes, F. (ed). (1989) Common Property Resources: Ecology and Community-Based Sustainable Development, Belhaven Press, London.

Berkes, F. (1993) "The Interface Between Natural and Social Systems" Background paper prepared for the Property Rights and The Performance of Natural Resource Systems September 1993 Workshop.

Boland, J. M. and Platteau, J. P. (1996)

Holding Degradation of Natural Resources: Is

There a Role for Rural Communities?

Clarendon Press, Oxford. whether conditions and other local physical characteristics. The rules must be formulated by all states through a river basin commission like SADC's soon- to- be- operational Zambezi River Basin Commission.

- Still on shared watercourses it may be beneficial for riparian states to learn from best practices and international river commissions at work. These include, for example, The Rhine River Commission in Europe and The Mekong River Commission in Asia.

- On gender, women must be given a greater role in decision-making about environmental issues at local, national and international levels. In particular, women's organizations should be consulted on questions of local environmental planning as well as being involved in the development and implementation of national conservation and sustainable development strategies, and finally;

- There is also need for gender mainstreaming in environmental planning and management issues given that women are the main users of CPRs and in the event that these resources are depleted, it's the women who are hardest hit.

- To reduce the bias of inheritance laws against women, legal reforms should concentrate on the promotion of joint ownership by husbands and wives of land and other property in areas where form of freehold are common.

Chiuta, T. M. (2000) "Shared Water Resources and Conflicts: The Case of Zambezi River Basin" in Tevera and Moyo (Eds) Environmental Security in Southern Africa, (2000), University of Zimbabwe, Harare.

Cooper, B.M. (1997) Marriage in Maradi: Gender and Culture in a Hausa Society in. Niger, 1900-1989, Heinemann, Portsmouth. Grimble, R. and Wellard, K. (1997)

Methodologies in Natural Resources Management" Agricultural Systems, Vol.55, No.2, pp173-179.

Hackett, S.C. (1998) Environmental and Natural Resources Economics, Armonk, New York. 
Hilhorst, T. (2002) "Changing Rights to Common Pool Resources and Land in West Africa" in Natural Resources Management and Gender: A Global Source Book. KIT Royal Tropical Institute, Amsterdam. Lavigne, D.P.C.; Toulman, J. P. and Chauveau, J. P. (2002) Negotiating access to Land Rights in West Africa. IIED/GRET/IRDREFO, London.

Libiszewski, S. (1992) "What is an Environmental Conflict?" Paper presented at the first Coordination meeting of the environment and conflict project (ENCOP) in Berne/ Zurich, April 30-May 1, 1992. Madzudzo, E. (1998) "Community Based Natural Resource Management in Zimbabwe: Opportunities and constraints". CASS working Paper- NRM series; CPN101/98 CASS. University of Zimbabwe.

Matondi, P. (2000)"Access to Land and Water Resources in Zimbabwe's Rural Environments" in Tevera and Moyo (Eds) Environmental Security in Southern Africa, (2000), University of Zimbabwe, Harare. Mogwe and Tevera D.S. (2000) "Land Rights of the Basarwa People of Botswana". In Tevera and Moyo (Eds) Environmental Security in Southern Africa, (2000), University of Zimbabwe, Harare.

Moyo, S.; O'Keefe, P. and Sill, M. (1993) The Southern African Environment. Profiles of The
SADC Countries. Earthscan Publications, London.

Mgugu, A. and Chimonyo, R. (2004) "Land Reform and Gender in Zimbabwe" in Masiiwa, M. (Ed) Post Independence Land Reform in Zimbabwe: Controversies and Impact on the Economy, Harare.

Ribbot, J. C. (2001) "Local Actors, Powers and Accountability in African Decentralizations:

Review of Issues" Draft.

SADC/IUCN/SARDC, (2001) A Guide to State of Environment Reporting in Southern Africa. CEP, Maseru/ Harare.Tevera, D. S. and Moyo, S. (Eds) (2000): Environmental Security in Southern Africa. SAPES, Harare. Tevera, D. S. and Mukora C. M. (2001) "Management of Common Property Resources in Agro-ecological Areas under Stress:

Institutional Issues, Resource use Conflicts and Options for Change". Unpublished Occasional paper, DGES/ITC, Harare.

Toulmin, C. (1997) "Participatory Management of Communal Resources". Paper Presented at the NRAC advisers Conference. Westing, A. H. (1986) Global Resource and International Conflict: Environmental Factors in Strategic Policy and Action. University of Oxford Press, Oxford.

Windstrand, C. (Ed) (1980) Water and

Security: Conflicts in Development, Pergamon Press, Oxford. 